\title{
Employees' Use Of Empathy To Improve Their Job Behaviour
}

Prakash Singh, Nelson Mandela Metropolitan University, South Africa

\begin{abstract}
Being simply cognitively capable would be inadequate for employees to satisfy job performance requirements associated with their job behaviour. Before an employee performs his job, he must understand what it entails because the activities and behaviours associated with a particular job are defined largely by the expectations and demands of other people, both inside and outside any organization. For instance, a teacher's role is defined by the expectations of his or her pupils, their parents, school managers, and society at large. In order to create positive relationships within the organization, employees need to offer encouraging words to each other when they try something new, be patient, understanding, and empathetic. The aim of the study is therefore to determine the need to develop empathy as a social skill of emotionally intelligent teachers.
\end{abstract}

The quantitative research method was used in this study. The findings strongly suggest that teachers must develop their social skill of empathy as part of their job behaviour. Empathy is an essential emotional intelligence trait for teachers to overtly include in their instructional strategies. Teachers who use instructional empathy will reduce anxiety and tension in the learning environment. Evidently, expressing empathy in the organization requires the employee to thoughtfully consider everyone's feelings in the process of making intelligent decisions. This study affirms that an employee who has a developed sense of empathy will have a much better understanding of how to handle different situations which could range from dealing with underachieving learners to working with gifted pupils.

Keywords: Empathy; Emotional Intelligence; Job Behaviour; Employees' Social Skills

\section{INTRODUCTION}

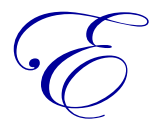

mpathy is a vital component of employees' emotional intelligence (EI) in shaping their job behaviour because "empathy is the ability to see the world from another person's perspective - the capacity to tune into what someone else might be thinking and feeling about a situation"- regardless of how that view might differ from their own perception (Stein \& Book, 2001, p. 112). Empathy empowers employees, such as teachers, to consider others' feelings, especially when making decisions (Goleman, 2011). Every employee occupies a position within the organization to which a role is attached, and this role is like a prescription in that it represents the activities and behaviours that are to be performed by a person who occupies that position (Churchill, Ford, \& Walker, 1990). Being simply cognitively capable would be inadequate for satisfying job performance requirements (Goleman, 1995; Mayer \& Salovey, 1997). Cherniss and Goleman (2004) state that EI is experiential when an individual demonstrates the competencies that comprise self-awareness, social awareness, self-management, and social skills, such as empathy at the correct times, and that the frequency should be effective in every situation. Schutte, Malouff, Hall, Haggerty, Cooper, Golden, and Dornheim (1998) assert that the study of intelligence has always been mainly focused on the adaptive use of cognition and not EI, while Nelson and Low (2011) believe that EI is the guide to accomplishing academic and career excellence and is a self-directed guide for everyone to acquire the contributions of their emotive mind.

In order to promote learning and nurture mindset growth, employees need to create a climate of inquiry and openness, of patience, and of encouragement (Kouzes \& Posner, 2013). Churchill, Ford, and Walker (1990) affirm that behaviour refers to what the workers actually "do; that is, the tasks they expend effort on while working" (p. 
729). Job behaviour would therefore include formally required and expected job behaviours and volitional or discretionary behaviours which are referred to as part of the psychological contract (Wei, 2012; Stiles, Gratton, Truss, Hope-Hailey, \& McGovern, 1997), as organizational citizenship behaviour (Al-Sharafi \& Rajiani, 2013; Bateman \& Organ, 1983), or as pro-social, organizational behaviour (Hyde, Harris, \& Boaden, 2013; Brief \& Motowidlo, 1986). In the Business Dictionary (Web Finance, 2013), job behaviour is defined as a pattern of actions and interactions of the members of an organization that directly or indirectly affects their productivity.

Before employees perform their jobs, they must understand what the jobs entail because the activities and behaviours associated with a particular job are defined largely by the expectations and demands of other people, both inside and outside any organization. For instance, a teacher's role is defined by the expectations of his or her pupils, their parents, school managers, and society at large. In order to create positive relationships within the organization, employees need to offer encouraging words to each other when they try something new - be patient, understanding, and empathetic "when they get off track and offer helpful suggestions as they try to learn and bounce back from mistakes" (Kouzes \& Posner, 2013, p. 204). Even when employees, such as teachers, have the aptitude to do their jobs and an understanding of what they are expected to do in the classrooms, they must also have the necessary interpersonal skills of empathy to accomplish their required tasks effectively. Singh (2010) argues that the human factor is not secondary to the existence of the organization. The happiness of employees is the key driver to achieve the vision of any organization and empathy forms a crucial component of this process. Churchill, Ford, and Walker (1990) justly point out that it is naïve to think that a happy worker is invariably a productive worker, but much evidence collected from a variety of occupations suggests that a worker's satisfaction does influence job behaviour. For instance, a negative relationship can appear between job satisfaction and absenteeism and employee turnover.

The employees' motivation to expend effort would therefore be a function of their expectancies that expending a given effort on their tasks would lead to improved job behaviour and performance (Churchill, Ford, \& Walker, 1990). Empathy shown by leaders can contribute to both the intrinsic and extrinsic job satisfaction of employees, and this is usually associated with the opportunities for their personal growth and accomplishment that the job provides (Mayer, Caruso, \& Salovey, 2000). Churchill, Ford, and Walker (1990) allude to the fact that "a worker's overall level of self-esteem and perceived ability to perform necessary tasks are positively related to the magnitude of the person's expectancy estimates" (p. 371). Hence, the amount of satisfaction employees get from their occupation is also influenced by their role perceptions because those who perceive large amounts of conflict in the demands placed on them tend to be less satisfied than those who do not. Empathy can be a powerful tool in organizations to eliminate such negative role perceptions (Goleman, 2011). It is therefore important for employees to balance EI and their IQ (Weare \& Gray, 2003). The importance of combining one's EI and IQ to create organisational effectiveness and job satisfaction is also supported by Caruso (1999) and is clarified by the following definition:

EI is the ability to use emotions to help you solve problems and live a more effective life. Emotional intelligence without intelligence, or intelligence without emotional intelligence, is only part of a solution. The complete solution is the head working with the heart. (p. 26)

Stein and Book (2001) confirm that empathy entails:

The ability to be aware of, to understand and to appreciate the feelings and thoughts of others. Empathy is "tuning in" (being sensitive) to what, how and why people feel and think the way they do. Being empathic means being able to "emotionally read" other people. Empathetic people care about others and show interest in and concern for them. (p. 111)

Empathy is an essential trait for teachers to overtly include in their instructional strategies. As aptly pointed out by Goleman (2011), empathy does not simply mean a kind of "I'm OK, you're OK" mushiness. Expressing empathy in the organization requires the employee to thoughtfully consider everyone's feelings in the process of making intelligent decisions. Teachers who use instructional empathy will reduce anxiety, tension, and the effects of tobephobia in the learning environment (Singh, 2010). When learners see their teachers expressing empathy, they feel more comfortable and open to talk about problems they may have in the classroom or even at home (Birch \& 
Ladd, 1996). If teachers want learners to succeed in their classes, it is important for them to connect with their learners on a professional and personal level (Seligman, 2005). Good listening skills are the key to genuine empathy because when teachers learn to listen better, they gain the respect of their pupils (Sterrett, 2000). Expectedly, empathy would increase trust and closeness within the organization and this would inevitably impact positively on the productivity and job satisfaction of employees (Singh, 2010).

Empathy is an emotion where people try to understand the minds of other people and try to see things from a different perspective that will explain the actions of one another (Stein \& Book, 2001; Goleman, 2011). It is also the process of how we interact with other minds and mostly coincide with other emotions such as caring for others (Coplan \& Goldie, 2011). A teacher who has a developed sense of empathy will have a much better understanding on how to handle different situations which could range from dealing with underachieving learners to working with gifted learners (Singh, 2010). Hence, the aim of the study was to determine the need to develop empathy as a social skill of emotionally intelligent teachers as part of their job behaviour. The main objective of this study was to determine the need for teachers to determine how empathy, as a social skill, can empower teachers in their jobs to provide quality and differentiated education to all learners in a heterogeneous learning environment. The problem statement for this study is, "Why is it necessary for teachers to develop empathy as an emotionally intelligent social skill to improve their job behaviour?"

\section{EMPATHIC TEMPERAMENT OF EMPLOYEES}

Empathy can be a powerful social skill in any organization (Goleman, 2011). However, as pointed out by Stein and Book (2001), it can be underutilized. Stein and Book justly point out that many people are prohibited from using empathy to their advantage because of three misconceptions about it. In the first instance, people confuse empathy with being "nice" - as opposed to what empathy really means. Secondly, many people confuse empathy with sympathy, and, thirdly, some people believe that by making an empathic statement, they would appear to be agreeing with or approving of the other person's position, when in fact they may be totally opposed to it. According to Whitefield and Kloot (2006), empathy is neither part of the implicit nor the explicit curriculum. Palmer (2013) states that empathy is one of the most important skills that teachers can and must teach to their learners, while Sagkal, Turnuklu, and Totan (2012) claim that empathy is the most important skill that should be learnt in schools. Ikiz (2009) asserts that people should create a balance between self-awareness and empathy in such a way that selfawareness emanates from empathy.

An empathic temperament has been seen as a popular attribute for teachers in a varied classroom, and this disposition is associated with an increase in sensitivity to different cultures (McAllister, 2002; Mayer, Caruso, \& Salovey, 2000). The empathetic disposition often also manifests itself in the teacher's caring relationship (McAllister, 2002). Studies have shown that learners who have a thoughtful connection with their educator are often more motivated and have the ability to perform at a greater academic level than students who do not share this bond (Singh, 2010). Studies have also proven that empathy can contribute to the success of a teacher (McAllister, 2002). In a recent study (Singh, 2013), it was found that there is a strong relationship between the ability to work with, appreciate, and respond to workers. The self-esteem of employees is higher in a working environment that encourages an empathic relationship amongst workers (Singh, 2013). Employees are motivated, to a greater extent, to excel which inevitably contributes to their job satisfaction. McAllister (2002) suggests that an increase in empathetic skills can improve classroom interactions by means of various attributes such as listening, being patient, reflecting constantly, and caring for the students. Singh (2013) stresses that EI is the potential of humans to succeed within a people-orientated environment.

Raver and Maydosz (2010) highlighted that learners who have made their own notes engage much more in the learning process than just giving learners already completed study notes. According to Rayneri, Gerber, and Wiley (2003), underachievement by learners is an infuriating occurrence for both teachers and parents. This is why teachers need to be flexible when dealing with the diverse learning needs of their learners. Noble early childhood educators fundamentally recognise that they are a significant influence on the future educational and life achievement of their scholars because they have been explicitly trained to have a child-focused view that cultivates social and emotional advance in young learners (Kremenitzer, 2005). Whitefield and Kloot (2006) confirm that behavioural skills, such as empathy, are often more complex and abstract than cognitive skills, as empathy involves 
a range of interpretations and a specific meaning in a given context while Ikiz (2009) argues that empathic skills refer to the ability for therapeutic techniques which can be developed by means of education. Culturally sensitive empathy is very important when working with a diverse cultural group, as found in all schools (Chung \& Bemark, 2002). Ickes (2003) believes that empathy is a skill that can and must be learned. Decety and Jackson (2004) also stated that empathy is a skill that is a product of accidental mutation which only occurs in humans and it is without any evolutionary history. For empathy and compassion to thrive, Cooper and Sawaf (1997) note that people need to be held responsible and accountable and be encouraged to face difficult situations without fear of failure. They suggest that empathy and compassion are the nucleus of collaboration and empowerment because without them, human feelings and emotions are ignored and workers then begin to stray from the organisation's core purpose because they are unhappy:

It is from empathy, especially when there is an environment of trust, that connection comes, one person to another. In terms of corporate and career achievements, it can be said that almost everything begins and ends in the emotions of confident relationships, in human connectedness. (p. 53)

Empathetic teachers will be able to accept certain barriers to learning and will be able to help their learners to overcome these barriers (Singh, 2010). These teachers will also be able to listen to the problems of their learners, even if these problems are not directly related to the content or even context of schooling. The teacher will also be able to understand the background of the learners, respect them, and their situations and, in the end, the learner will have more respect for the teacher (Ward, 2013). Hunter (2013) asserts that learners will bring their emotions, which will have a direct effect on how they learn, to the classroom and that a teacher must be able to connect with them and to understand them. Wilson (2011) also postulates that empathy is an important element needed for teachers to be able to transfer knowledge. As pointed out by Jackson, Meltzoff, and Decety (2005), empathy is a multi-faceted form of mental deduction where memory, observation, reasoning, and knowledge are combined to achieve new insights into the feelings and thoughts of others. Wiggins and McTighe (2005) state that empathy, together with explanation, interpretation, application, perspective, and self-knowledge, are all abilities that are important for a teacher and learner to achieve goals and to understand the contents of the curriculum. Wiggins and McTighe (2005) also define understanding as "a mental construct, an abstraction made by the human mind to make sense of many distinct pieces of knowledge" (p. 37). Parents have a duty to teach their children how to care for other people and how to be empathetic. However, their curriculum contributions can be limited owing to the fact that the parents' empathetic skills might be limited. Studies have proven that the teachers have a greater ability to influence the motivation and also the behaviour of learners than parents are able to (Narinasamy \& Wan Mamat, 2013).

Galinsky and Moskowitz (2000) argue that the active consideration of imagining how a learner is affected by what his or her situation produces, allows for an empathic arousal that can lead to the employee as a perspectivetaker to offer greater assistance to the learner. Wang, Chignell, and Ishizuka (2006) observed that attention loss by learners does not only occur when teaching in a virtual environment but also in any other teaching environment or learning area. Weare and Gray (2003) suggest that both emotional and social competencies should not only be taught at school, but also at higher education institutions that train teachers. Emotional competencies should be compulsory in schooling and be part of the objective of pre-service teacher training (Wang \& Huang, 2009; Palomera, Fernandez-Berrocal, \& Barckett, 2008). It should be considered as one of the most important basic competencies that employees at schools should have (Sagkal, Turnuklu, \& Totan, 2012). Undoubtedly, teachers who are emotionally intelligent can have a profound effect on the teaching and the achievement of their learners (Durlak, Weissberg, \& Pachan, 2005).

\section{RESEARCH DESIGN}

The quantitative research method was used to conduct the investigation in this study. A quantitative approach is one in which the investigators have primarily post-positivist claims for developing knowledge and employing strategies of inquiry, such as surveys. Muijs (2010) states that survey research is well suited where a researcher wants to look at the relationship between variables occurring in particular real-life contexts. The survey used in this investigation focused on the teachers' empathy as a social skill. A total of six schools participated in his exploratory study and from each school, six teachers were purposefully selected; altogether, 36 participants took part in this study. The structured questionnaire comprised two main sections - Section A required the participants to 
provide their biographic information relevant to this research and Section B of the questionnaire comprised twelve items focusing on the use of empathy by teachers as part of their instructional skills. The participants needed to respond to each statement by using the five-point Likert scale, ranging from Strongly Disagree to Strongly Agree. Necessary precautionary measures were taken to obtain ethical clearance for this study. All the participants had to give consent before they took part in this study. They were informed that their identities, as well as that of their schools, would not be disclosed, and confidentiality was observed at all times. They were also informed that participation in this study was voluntary. Participants could withdraw from the study at any point without any consequences. Once a participant wanted to withdraw from the study, all information gathered from that specific participant would be discarded. The participants were informed that there were no risks involved in participating as they were required to complete the questionnaire at their respective schools.

\section{DISCUSSION OF FINDINGS}

Descriptive and inferential statistics were used to analyse the data. The main objective of using inferential statistics is to determine whether significant and meaningful patterns are present in the research results (Gravetter \& Wallnau, 2008). Reliability testing was also done with Cronbach's $\alpha$ being equal to 0.62 . This indicated that the questionnaire was, for all practical purposes, reliable. In terms of content validity, the questionnaire was initially approved by five teachers, an academic, and the statistician who analysed the data.

\section{Biographical Data of Participants}

Table 1 displays the relevant biographical information of the participants who took part in this study, most of who fall within the 20-39 age bracket. In contrast, only $3.13 \%$ of the participants are in the $60+$ age bracket. More than half the participants comprised females $(56.25 \%)$. The highest level of education indicated that $84.37 \%$ of the participants had degree qualifications.

Table 1: Biographic Data of Participants $(n=32)$

\begin{tabular}{|c|c|c|c|}
\hline \multicolumn{2}{|c|}{ Age Group } & \multicolumn{2}{|c|}{ Gender } \\
\hline $20-29$ & $31.25 \%$ & Male & $43.75 \%$ \\
\hline $30-39$ & $25 \%$ & Female & $56.25 \%$ \\
\hline $40-49$ & $15.62 \%$ & & \\
\hline $50-59$ & $25 \%$ & \multicolumn{2}{|l|}{ Position } \\
\hline $60+$ & $3.13 \%$ & Subject Teacher & $78.13 \%$ \\
\hline & & Head of Department & $9.37 \%$ \\
\hline \multicolumn{2}{|c|}{ Number of Years in Employment } & Deputy Principal & $3.13 \%$ \\
\hline $1-5$ & $34.38 \%$ & Principal & $9.37 \%$ \\
\hline $6-10$ & $28.12 \%$ & & \\
\hline $11-15$ & $6.25 \%$ & \multicolumn{2}{|c|}{ Highest Level of Education } \\
\hline $16-20$ & $3.13 \%$ & Grade 12 or lower & $3.13 \%$ \\
\hline $21+$ & $28.12 \%$ & Teaching Diploma & $12.50 \%$ \\
\hline & & Degree & $9.36 \%$ \\
\hline \multicolumn{2}{|c|}{ Home Language } & Degree Plus a Teaching Diploma & $43.75 \%$ \\
\hline English & $31.25 \%$ & Post Graduate Degree & $21.88 \%$ \\
\hline Afrikaans & $68.75 \%$ & Post Graduate Degree Plus a Teaching & $9.38 \%$ \\
\hline
\end{tabular}

\section{Item Analysis}

Table 2 shows the responses of the participants, as well as the mean average and the standard deviation for each statement. The table indicates that participants responded positively (mean average above 3 ) in all items except for when considering items seven and eleven, each scoring a mean average of 2.34 . A total of $68.75 \%$ of the participants disagreed with item seven, indicating that they do not show empathy only to high risk learners at the expense of other ability learners; thus, it can be seen as a positive response. It was also found that $56.25 \%$ of the participants disagreed with item eleven, indicating that teachers do not easily empathise with learners who do not speak the official language of the school by allowing learners to use code switching of languages to improve their communication ability. 
Table 2: Summary of Responses to the Survey

\begin{tabular}{|c|c|c|c|c|c|c|c|c|}
\hline Item & & SD & D & $\mathbf{N}$ & $\mathbf{A}$ & SA & Mean & $\begin{array}{l}\text { Standard } \\
\text { deviation }\end{array}$ \\
\hline 1 & $\begin{array}{l}\text { Emotional intelligence is not given } \\
\text { the same recognition as cognition in } \\
\text { developing teachers' professional } \\
\text { competencies to cope with the } \\
\text { constant changes in education }\end{array}$ & $0 \%$ & $0 \%$ & $3.125 \%$ & $75 \%$ & $21.875 \%$ & 4.19 & 0.47 \\
\hline 2 & $\begin{array}{l}\text { Emotionally intelligent teachers } \\
\text { depend on empathy as a social skill } \\
\text { to plan their lessons }\end{array}$ & $0 \%$ & $12.5 \%$ & $21.875 \%$ & $53.125 \%$ & $12.5 \%$ & 3.66 & 0.87 \\
\hline 3 & $\begin{array}{l}\text { Empathy allows the teachers to } \\
\text { demonstrate humanistic values in } \\
\text { their choice of learning materials for } \\
\text { learners of different abilities }\end{array}$ & $0 \%$ & $0 \%$ & $12.5 \%$ & $59.375 \%$ & $28.125 \%$ & 4.16 & 0.63 \\
\hline 4 & $\begin{array}{l}\text { Empathy gives teachers flexibility to } \\
\text { identify with the individual learning } \\
\text { needs of their diverse ability learners } \\
\text { by not adhering strictly to a } \\
\text { standardised assessment approach }\end{array}$ & $0 \%$ & $0 \%$ & $18.75 \%$ & $53.125 \%$ & $28.125 \%$ & 4.13 & 0.66 \\
\hline 5 & $\begin{array}{l}\text { Teachers show empathy to high risk } \\
\text { learners (who fail to understand the } \\
\text { subject matter easily) by preparing } \\
\text { special worksheets for them }\end{array}$ & $9.375 \%$ & $18.75 \%$ & $12.5 \%$ & $34.375 \%$ & $25 \%$ & 3.47 & 1.32 \\
\hline 6 & $\begin{array}{l}\text { Teachers show empathy to high risk } \\
\text { learners by slowing the pace of } \\
\text { instruction for them }\end{array}$ & $6.25 \%$ & $6.25 \%$ & $9.375 \%$ & $43.75 \%$ & $34.375 \%$ & 3.88 & 1.13 \\
\hline 7 & $\begin{array}{l}\text { Teachers show empathy only to high } \\
\text { risk learners at the expense of other } \\
\text { ability learners }\end{array}$ & $12.5 \%$ & $56.25 \%$ & $15.625 \%$ & $15.625 \%$ & $0 \%$ & 2.34 & 0.90 \\
\hline 8 & $\begin{array}{l}\text { Teachers design differentiated } \\
\text { learning activities for advanced } \\
\text { ability learners }\end{array}$ & $3.125 \%$ & $18.75 \%$ & $15.625 \%$ & $56.25 \%$ & $6.25 \%$ & 3.44 & 0.98 \\
\hline 9 & $\begin{array}{l}\text { Advanced ability learners are not } \\
\text { given more of the same subject } \\
\text { matter just to keep them busy and } \\
\text { quiet }\end{array}$ & $12.5 \%$ & $34.375 \%$ & $6.25 \%$ & $40.625 \%$ & $6.25 \%$ & 3.16 & 1.22 \\
\hline 10 & $\begin{array}{l}\text { Teachers are easily approachable } \\
\text { and sensitive to the diverse needs of } \\
\text { their learners from different } \\
\text { communities }\end{array}$ & $3.125 \%$ & $9.375 \%$ & $18.75 \%$ & $46.875 \%$ & 21.875 & 3.75 & 1.02 \\
\hline 11 & $\begin{array}{l}\text { Teachers easily empathise with } \\
\text { learners who do not speak the } \\
\text { official language of the school by } \\
\text { allowing learners to use code } \\
\text { switching of languages to improve } \\
\text { their communication ability }\end{array}$ & $18.75 \%$ & $37.5 \%$ & $34.375 \%$ & $9.375 \%$ & $0 \%$ & 2.34 & 0.90 \\
\hline 12 & $\begin{array}{l}\text { Teachers demonstrate empathy by } \\
\text { promoting multicultural values in } \\
\text { their curriculum by integrating } \\
\text { artefacts from different religions on } \\
\text { a voluntary basis }\end{array}$ & $9.375 \%$ & $18.75 \%$ & $25 \%$ & $37.5 \%$ & $9.375 \%$ & 3.19 & 1.15 \\
\hline
\end{tabular}

Item 1

The biographic data in Table 1 were compared to the responses to item one. Age had a p-value $=0.33595$, gender 0.51420 , years' service 0.12429 , position at school 0.984 , home language 0.2149 , and highest level of education 0.61838 . No results with a p-value equal to or less than $0.05(5 \%)$ were obtained, indicating that there are no significant relationships between the biographical data of each participant and item one. This suggests that EI is not given the same recognition as cognition in developing teachers' professional competencies to cope with the constant changes in education, and this was confirmed by $96.875 \%$ of the respondents. 
Item 2

All the biographic data (Table 1) were compared to the responses to item two. Age had a p-value = 0.08338 , gender 0.98152 , years' service 0.31328 , position at school 0.66038 , home language 0.61617 , and highest level of education 0.30877 . No results with a p-value equal to or less than $0.05(5 \%)$ were obtained, indicating that there are no significant relationships between the biographical information of each participant and item two. It can therefore be concluded that the use of empathy as a social skill to plan lessons is equally important to participants, irrespective of their biographic background. Learners can easily lose attention, especially in a computer-based teaching environment that is not custom-made to their needs. However, the loss of attention by learners does not only occur when teaching in a computer-orientated classroom, but also in any other teaching environment or learning area (Wang et al., 2006). A total of $65.625 \%$ of the participants stated that they depend on empathy as a social skill to plan their lessons, which leaves more than a third of the participants who do not provide for their learners' needs, be it catering for different learning styles or merely making lessons interesting to keep learners interested. As pointed out by Weare and Gray (2003), both emotional and social competencies should not only be taught in the schools' curriculum, but must also be included in the curriculum of institutions that train teachers.

Item 3

All the biographic data (Table 1) were compared to the responses to item three. In total, $87.5 \%(59.375 \%$ agreed and $21.125 \%$ strongly agreed) of the participants agreed with the statement that empathy allows teachers to demonstrate humanistic values in their choice of learning materials for learners of different abilities. Furthermore, $12.5 \%$ of the participants chose to stay neutral and none of the participants disagreed with item three. Age had a pvalue $=0.02907$, gender 0.6245, years' service 0.56852, position at school 0.70169 , home language 0.27966 , and highest level of education 0.93790. Age is the only biographic variable that has a p-value less than 0.05 , which means that there is a significant relationship between the age of teachers and the humanistic values they demonstrate in the choosing of learning materials for learners of different abilities.

It is clear to all teachers that not all learners have the same learning abilities. It is therefore important for teachers to identify the different learning abilities of learners in their classroom and to select content that is appropriate to the level of the learners. It is also important to select learning material that learners can identify with so that they can understand the context in which teachers are teaching them. It could be considered to give learners notes that they can follow as teachers teach, but also leave space on the notes for learners to make their own notes and comparisons, as it has been proved by Raver and Maydosz (2010) that learners making their own notes engages them a lot more in the learning process than just giving learners already completed study notes. Noble early childhood educators fundamentally recognise that they are a significant influence on the future educational and life achievement of their scholars because they have been explicitly trained to have a child-focused view that cultivates social and emotional advance in young learners (Kremenitzer, 2005).

What has been found in this exploratory study is that the younger the teachers are, the more empathetic they are toward their learners when choosing learning materials for learners with different learning abilities. The rest of the biographical information compared to item three revealed no significant results, indicating that it is equally important for all teachers to demonstrate humanistic values in their choice of learning materials for learners of different abilities, irrespective of their biographic background. The only aspect of teachers that will affect their demonstration of humanistic values, in their choice of learning materials for learners of different abilities, is their age. However, more research needs to be done on the relationships between age and empathy of teachers.

Item 4

The biographic data in Table 1 were compared to the responses to item four. Age had a p-value $=0.20453$, gender 0.48834 , years' service 0.39656 , position at school 0.62153 , home language 0.56983 , and highest level of education 0.36437 . No results with a p-value equal to or less than $0.05(5 \%)$ were obtained, indicating that there are no significant relationships between the biographical information of each participant and item four. This indicates that the flexibility of teachers to identify with the individual learning needs of the learners is equally important to all the participants, irrespective of their biographic background. 
According to Rayneri, Gerber, and Wiley (2003), underachievement by learners is a frustrating experience for both teachers and parents. This is why teachers need to be flexible when dealing with the diverse learning needs of their learners. Being flexible in this context will mean that teachers will try to cater for all their learners' diverse learning needs. In total, $81.25 \%$ (53.125\% agreed and $28.125 \%$ strongly agreed; see Table 2) agreed with the statement that empathy gives teachers flexibility to identify with the individual learning needs of their diverse ability learners by not adhering strictly to a standardized assessment approach. None of the participants disagreed and $18.75 \%$ chose to stay neutral when answering this statement. Research shows that an empathetic teacher will be able to accept certain barriers to learning and will be able to help their learners to overcome these barriers (Ward, 2013). Many teachers provide additional worksheets for these learners as this can help them close the gap they are missing or to revise until the content is understood. Teachers should listen to their learners without criticism, commentary, or advice. When a teacher shows empathy, it does not mean that they approve or agree with the learner, but instead they are trying to understand the learner and his/her needs. In the case of teachers showing empathy to high risk learners by preparing special worksheets for them, it is these high risk learners who fail to understand the subject matter easily (Eysenk \& Calvo, 1992). They are therefore given multiple opportunities to understand and assimilate the subject matter.

Item 5

All the biographic data (Table 1) were compared to the responses to item five. Age had a p-value = 0.78960 , gender 0.13986 , years' service 0.61020 , position at school 0.36601 , home language 0.20493 , and highest level of education 0.26224 . No results with a p-value equal to or less than $0.05(5 \%)$ were obtained, indicating that there are no significant relationships between the biographical information of each participant and item five. This means that it is equally important for all teachers to show empathy to high risk learners (who fail to understand the subject matter easily) by preparing special worksheets for them irrespective of their biographic background.

Teachers need to be able to recognise possible signs which indicate that individuals are in a variety of emotional states and they should try and assist their proteges to deal with their situation (Singh, 2010). In other words, identify the high risk learners and then slow down the pace of instruction for them. This should be done in such a way that the "faster" learners are not disadvantaged by having to wait for other learners. A possible solution could be that of slowing down the pace for high risk learners, but then having additional and more intense examples or notes for the "faster" learners to carry on with. Research on empathy and academic outcomes indicates impressive correlations between learners' scores on measures of empathetic understanding and grade point averages, higher reading comprehension, and enhanced critical thinking skills and creative thinking (Berman, 2004).

\section{Item 6}

All the biographic data (Table 1) were compared to the responses to item six. Age had a p-value $=0.47027$, gender 0.08070, years of service 0.29946 , position at school 0.30502 , home language 0.83612 , and highest level of education 0.22460 . No results with a p-value equal to or less than $0.05(5 \%)$ were obtained indicating that there are no significant relationships between the biographical information of each participant and item six. This indicates that it is equally important for all teachers, irrespective of their biographic background to slow down the pace of instruction for high risk learners. Berman (2004) stated that empathy training programmes for therapists, teachers and parents have been shown to be valuable for heightening affective and cognitive empathy. These programmes emphasize role-taking, which was pioneered by an anthropologist Mead (2000) as well as by Rogers (1945). Empathy training programmes include training in interpersonal perception and empathetic responding, as well as locating the similarities between oneself and others.

\section{Item 7}

All the biographic data (Table 1) were compared to the responses to item seven. Age had a p-value $=$ 0.13370 , gender 0.09007 , years of service 0.09441 , position at school 0.75012 , home language 0.76485 , and highest level of education 0.10750 . No results with a p-value equal to or less than $0.05(5 \%)$ were obtained, indicating that there are no significant relationships between the biographical information of each participant and item seven. This indicates that it is equally important for all teachers not to show empathy only to high risk learners at the expense of 
other ability learners, irrespective of their biographic background. A total of $68.75 \%$ of the respondents disagreed with the statement. According to Rose and Meyer (2002), teachers need a framework that will teach all learners a general education setting. One such framework is universal design for learning (UDL). The goal of UDL is to create flexible activities that will give options of learners with disparities, inabilities, and background. If an activity consists of three questions, the lower level learner will be able to do one-third of the activity; the middle level learner will be able to do two-thirds; and the high level learner can complete the whole activity. In an ideal school, it would be great to be able to design different activities for different level learners; but in reality, a teacher does not have the time to do this for each class. With UDL, all learners will be able to complete a part of the activity which helps to create an activity for all the different level learners in one class.

Item 8

All the biographic data (Table 1) were compared to the responses to item eight. Age had a p-value $=$ 0.85619 , gender 0.55553 , years of service 0.13781 , position at school 0.34949 , home language 0.09936 , and highest level of education 0.00118 . The highest level of education of the participants is the only biographic variable that has a p-value less than 0.05 , which means that there is a significant relationship between the highest level of education and the different types of activities given to learners. It would be expected that teachers with better qualifications would be more efficient in individualizing and differentiating learning for their pupils. A total of $62.5 \%$ agreed with the statement which could be linked to the participants having higher qualifications than their peers in the profession.

No results with a p-value equal to or less than $0.05(5 \%)$ were obtained, indicating that there are no significant relationships between the rest of the biographical information of each participant and item eight. This indicates that it is equally important to all teachers to design differentiated learning activities for advanced ability learners, irrespective of their biographic information. Educators are guilty of setting a slow pace in the classroom so that every level learner is on the same page. Teachers want to ensure everyone understands the same contents before moving on to the next section of the curriculum. Unfortunately, it is the advanced learner who is disadvantaged. Advanced ability learners, who are not being challenged, do not reach their full potential in a large class as compared to a technology-enriched classroom where every level of learner is challenged. Studies on differentiated education have confirmed that the technology-enriched classroom differed from the traditional classroom in several significant ways and that it truly develops learners with varying abilities (Singh, 2010).

Item 9

All the biographic data (Table 1) were compared to the responses to item nine. Age had a p-value $=$ 0.07833 , gender 0.08979 , years of service 0.03022 , position at school 0.01014 , home language 0.75015 , and highest level of education 0.07889 . The highest level of education is the only biographic variable that has a p-value less than 0.05 , which means that there is a significant relationship between teachers who go that extra mile to develop extra activities for the advanced ability learner in their class. The findings of this item suggest that teachers with more years of experience and in management positions have more empathy than the younger teachers with less experience. There was an equal split in response to this item - a total of $46.875 \%$ of participants agreed to this statement, while $46.875 \%$ disagreed. More research needs to be done on the curriculum issue of assigning advanced ability learners with more of the same work which falls short of their ability level.

Item 10

All the biographic data (Table 1) were compared to the responses to item ten. Age had a p-value $=0.12098$, gender 0.12797 , years of service 0.12232 , position at school 0.92701 , home language 0.80655 , and highest level of education 0.69493 . No results with a p-value equal to or less than $0.05(5 \%)$ were obtained, indicating that there are no significant relationships between the biographical information of each participant and item 10. This indicates that it is equally important to all teachers that they are easily approachable and sensitive to the diverse needs of their learners from different communities. 
Item 11

All the biographic data (Table 1) were compared to the responses to item 11. Age had a p-value $=0.64941$, gender 0.39619 , years of service 0.76570 , position at school 0.81674 , home language 0.04630 , and highest level of education 0.91422. It was found that the Afrikaans-speaking participants are more empathetic toward the home language of their learners than the English-speaking participants. This means that Afrikaans-speaking teachers are more likely to allow learners to try to communicate in the language they feel comfortable with than Englishspeaking teachers. Other than the home language of the participants, no results with a p-value equal to or less than $0.05(5 \%)$ were obtained, indicating that there are no significant relationships between the biographical information of each participant and item 11.

Item 12

All the biographic data (Table 1) were compared to the responses to item 12. Age had a p-value $=0.15552$, gender 0.37543 , years of service 0.50478 , position at school 0.59492 , home language 0.85153 , and highest level of education 0.33972 . No results with a p-value equal to or less than $0.05(5 \%)$ were obtained, indicating that there are no significant relationships between the biographical information of each participant and item 12 . This means that it is equally important for teachers to demonstrate empathy by promoting multicultural values in their curriculum by integrating artefacts from different religions on a voluntary basis, irrespective of their biographic background. As Sagkal, Turnuklu, and Totan (2012) stated, empathy is the most important skill that should be taught, learnt, and practised in schools. Kouzes and Posner (2013) assert that when relating hopes, dreams, and successes, people are almost emotionally expressive. They contend that expressiveness "comes naturally when talking about deep desires for the something that could be better in the future than it is today, and it doesn't matter what language they are speaking" (p. 140). Leach (2013) aptly sums up the importance of employees having a caring mentality to improve their job behaviour as follows:

Caring is a powerful human emotion that engages others. Those teams that care are far more likely to achieve what they set out to achieve than those that don't. It is quite common for a successful team to be motivated by the fear of letting others down - those that matter to them, whether customers, fans, followers or family. (p. 100)

\section{CONCLUSION}

It is evident from the findings of this study that no one person can single-handedly educate a child collegial collaboration and teaming amongst employees in schools contribute to the mission and vision of these organizations being achieved. In terms of the findings in this exploratory study, it is clear that the hallmarks of empathy for employees includes expertise in attracting and developing talent in their organizations, having the ability to develop others, and demonstrating sensitivity to cross-cultural differences. Employees must be afforded the opportunity to develop their ability as leaders whose expertise defines what they are capable of accomplishing in the organization. IQ alone would not suffice to attain this noble objective. Hence, it is imperative that for employees using an empathetic approach, they develop cooperative goals and roles, foster collaboration and create a climate of trust, support norms of reciprocity, and ultimately show concern for others. The umbilical link between employees' job performance and their empathetic behaviour needs to be strengthened in all organizations. Nothing less should be exacted. More compelling research needs to be undertaken on this subject.

\section{AUTHOR INFORMATION}

Prakash Singh is a professor at the Nelson Mandela Metropolitan University in Port Elizabeth, South Africa. He is an NRF rated researcher and a Fulbright scholar. His niche research areas of publication focus on social psychology and human behaviour. Professor Singh is the author of Innovative Strategies to Develop Better Schools and coauthor of Principal Leadership. He has also published widely in peer-reviewed journals and has presented numerous papers at international conferences. E-mail: Prakash.Singh@nmmu.ac.za 


\section{REFERENCES}

1. Al-Sharafi, H., \& Rajiani, I. (2013). Promoting organizational citizenship behavior among employees - the role of leadership practices. International Journal of Business and Management, 8(6), 47-54.

2. Bateman, T. S., \& Organ, D. W. (1983). Job satisfaction and the good soldier: The relationship between affect and employee citizenship. The Academy of Management Journal, 26(4), 587-595.

3. Berman, J. (2004). Empathic teaching: Education for life. Boston: University of Massachusetts Press.

4. Birch, S. H., \& Ladd, G. W. (1996). Interpersonal relationships in the school environment and children's early school adjustment: The role of teachers and peers. In J. Juvenon \& K. Wentzel (Eds.), Social motivation: Understanding children's school adjustment. New York: Cambridge University Press.

5. Brief, A. P., \& Motowidlo, S. J. (1986). Prosocial organizational behaviors. The Academy of Management Review, 11(4), 710-725.

6. $\quad$ Caruso, D. (1999). Multifactor emotional intelligence. New York: Basic Books.

7. Cherniss, C., \& Goleman, D. (2004). The emotional intelligent workplace. San Francisco: Wiley and Sons.

8. Chung, R. C., \& Bemark, F. (2002). The relationship of culture and empathy in cross-cultural counselling. Journal of Counselling and Development, 1(80), 154-159.

9. Churchill, G. A., Ford, N. M., \& Walker, O. C. (1990). Sales force management. Homewood, IL: Irwin.

10. Cooper, R., \& Sawaf, A. (1997). Executive EQ: Emotional intelligence in business. London: Texere.

11. Coplan, A., \& Goldie, P. (2011). Empathy: Philosophical and psychological perspectives. New York: Oxford.

12. Decety, J., \& Jackson, P. L. (2004). The functional architecture of human empathy. Journal of Behavioural and Cognitive Neuroscience Reviews, 3(2), 71-100.

13. Durlak, J. A., Weissberg, R. P., \& Pachan, M. (2005). A meta-analysis of after-school programs that seek to promote personal and social skills in children and adolescents. American Journal of Community Psychology, 45(4), 294-309.

14. Eysenk, M. W., \& Calvo, M. G. (1992). Anxiety and performance: The processing efficiency theory. Cognitive Emotion, 6, 409-434.

15. Galinsky, A. D., \& Moskowitz, G. B. (2000). Perspective-taking: Decreasing stereotype expression, stereotype accessibility, and in-group favouritism. Journal of Personality and Social Psychology, 79(4), 708-724.

16. Goleman, D. (1995). Emotional intelligence. New York. Bantam Books.

17. Goleman, D. (2011). What makes a leader. In HBR'S 10 must reads. Boston, Massachusetts: Harvard Business Review Press.

18. Gravetter, F. J., \& Wallnau, L. B. (2008). Essentials of statistics for the behavioural sciences. New York: Thompson Wadsworth.

19. Hunter, K. (2013). Empathy in education. Retrieved from ,http://www.empathyed.org/index.php? option $=$ com_content \&view $=$ category\&id $=37 \&$ Itemid $=63$

20. Hyde, P., Harris, C., \& Boaden, R. (2013). Pro-social organizational behaviour of health care workers. International Journal of Human Resource Management, 24(16), 3115-3130.

21. Ickes, W. (2003.) Everyday mind reading. New York: Prometheus.

22. Ikiz, F. E. (2009). Investigation of counsellor empathy with respect to safe schools. Procedia Social and Behavioural Sciences, 1, 2057-2062.

23. Jackson, P. L., Meltzoff, N., \& Decety, J. (2005). How do we perceive the pain of others? A window into the neural processes involved in empathy. Neuro Image, 24, 771-779.

24. Kouzes, J., \& Posner, B. (2013). The leadership challenge. San Francisco, CA: Jossey-Bass.

25. Kremenitzer, J. P. (2005). The emotionally intelligent early childhood educator: Self-reflective journaling. Early Childhood Education Journal, 33(1), 3-9.

26. Leach, J. (2013). The success factor. Petaling Jaya, Malaysia: Advantage Quest Publications.

27. Mayer, J. D., Caruso, D. R., \& Salovey, P. (2000). The handbook of emotional intelligence: Theory, development, assessment, and application at home, school and in the workplace. San Francisco: JosseyBass.

28. Mayer, J. D., \& Salovey, P. (1997). What is emotional intelligence? Emotional development and emotional intelligence: Implications for educators. New York: Basic Books.

29. Mead, M. (2000). And keep your power dry: An anthropologist looks at America. New York: Morrow. 
30. McAllister, G. (2002). The role of empathy in teaching culturally diverse students. Journal of Teacher Education, 53(5), 433-443.

31. Muijs, D. (2010). Doing quantitative research in education with SPSS. New York: Sage.

32. Narinasamy, I., \& Wan Mamat, W. H. (2013). Caring teacher in developing empathy in moral education. The Malaysian Online Journal of Educational Science, 1(1), 1-19.

33. Nelson, D. B., \& Low, G. R. (2011). Emotional intelligence: Achieving academic and career excellence. Boston: Prentice Hall.

34. Palmer, S. (2013). Empathy: Why it's important, why we should nurture it in our kids. Retrieved from http://www.parentfurther.com/blog/raising-empathetic-kids

35. Palomera, R., Fernandez-Berrocal, P., \& Barckett, M. A. (2008). Emotional Intelligence as a basic competency in pre-service teacher training: Some advice. Journal of Research in Educational Psychology, 6(2), 437-454.

36. Raver, S. A., \& Maydosz, A. S. (2010). Impact of the provision and timing of instructor-provided notes on university students' learning. Active Learning in Higher Education, 11(3), 189-200.

37. Rayneri, L. J., Gerber, B. L., \& Wiley, L. P. (2003). Gifted achievers and gifted underachievers: The impact of learning style preferences in the classroom. The Journal of Secondary Gifted Education, 15(4), 197-204.

38. Rogers, C. R. (1945). The nondirective method as a technique for social research. American Journal of Sociology, 50(4), 279-283.

39. Rose, D. H., \& Meyer, A. (2002). Teaching every student in the digital age: Universal design for learning. Alexandria, VA: Association for Supervision and Curriculum Development.

40. Sagkal, A. S., Turnuklu, A., \& Totan, T. (2012). Empathy for interpersonal peace: Effects of peace education on empathy skills. Educational Sciences: Theory and Practice, 12(2), 1454-1460.

41. Schutte, N. S., Malouff, J. M., Hall, L. E., Haggerty, D. J., Cooper, J. T., Golden, C. J., \& Dornheim, L. (1998). Development and validation of a measure of emotional intelligence. Personality and Individual Differences, 25, 167-177.

42. Seligman, M. E. P. (2005). La autentica felicidad. [Genuine happiness.]. Barcelona: Ediciones.

43. Singh, P. (2010). Innovative strategies to develop better schools. Sydney, Australia: Common Ground.

44. Singh, P. (2013). A collegial approach in understanding leadership as a social skill. International Business \& Economics Research Journal, 12(5), 489-502.

45. Stein, S. J., \& Book, H. E. (2001). The EQ edge. New York: Stoddart.

46. Sterrett, E. A. (2000). Emotional intelligence. Amherst, Massachusetts: HRD Press.

47. Stiles, P., Gratton, L., Truss, C., Hope-Hailey, V., \& McGovern, P. (1997). Performance management and the psychological contract. Human Resource Management Journal, 7(1), 57-66.

48. Wang, H., Chignell, M., \& Ishizuka, M. (2006). Empathic tutoring software agents using real-time eye tracking. Retrieved from http://pdf.aminer.org/000/190/375/empathic_tutoring_software _agents_using_real_time_eye_tracking.pdf

49. Wang, Y. S., \& Huang, T. C. (2009). The relationship of transformational leadership with group cohesiveness and emotional intelligence. Social Behaviour and Personality, 37(3), 379-92.

50. Ward, L. (2013.). Philosophy of education. Retrieved from http://lisaward716.tripod.com/id1.html

51. Weare, K., \& Gray, G. (2003). What works in developing children's emotional and social competence and well being. London: Crown Printers.

52. Web Finance. Business dictionary. (2013). Retrieved from http://www.businessdictionary.com/definition/ job-performance.html

53. Wei, Y. C. (2012). What can benefit organizational citizenship behavior to job performance? The role of human capital. The Asian Business and Management Conference Proceedings. Osaka, Japan: National Taipei University of Education.

54. Whitefield, D., \& Kloot, L. (2006). Personal and interpersonal skills: The process of prescribing definitions in an accounting degree. Asian Review of Accounting, 14(2), 101-121.

55. Wiggins, G., \& McTighe, J. (2005). Understanding by design. Alexandria, VA: Association for Supervision and Curriculum Development.

56. Wilson, J. C. (2011). Service-learning and the development of empathy in US college students. Education and Training, 53(3), 207-217. 